\title{
Co-transfer of plasmids in association with conjugative transfer of mupirocin or mupirocin and penicillin resistance in methicillin-resistant Staphylococcus aureus
}

\author{
A. PAWA, W. C. NOBLE and S. A. HOWELL* \\ Department of Microbial Diseases, St John's Institute of Dermatology, St Thomas' Hospital, \\ London SE1 7EH
}

\begin{abstract}
Two distinct strains of methicillin-resistant Staphylococcus aureus (MRSA) isolated from patients in a dermatology ward were also resistant to mupirocin. The mupirocin resistance plasmids from both strains were indistinguishable by EcoRI and HindIII restriction digest analysis, except for the presence of genes apparently mediating penicillinase production in some transconjugants. Conjugative transfer of the plasmid mediating mupirocin resistance from one of these strains to a recipient $S$. aureus was accompanied in some cases by co-transfer of plasmids mediating resistance to tetracycline or erythromycin; in some instances a plasmid which possessed no apparent resistance markers was also transferred. The second strain demonstrated conjugative transfer of penicillin and mupirocin resistance as well as transfer of a plasmid mediating gentamicin resistance, but transfer of erythromycin resistance was not apparently plasmid-mediated.
\end{abstract}

\section{Introduction}

In the late $1970 \mathrm{~s}$ and early $1980 \mathrm{~s}$, studies on the transfer of plasmids mediating gentamicin resistance between strains and between species of staphylococci firmly established conjugative transfer as a mechanism whereby resistance genes borne on plasmids could be disseminated in this genus [1-4]. In some instances, conjugative transfer was also found to encompass the co-transfer of other, smaller, plasmids which transferred at extremely low or undetectable frequencies in the absence of the conjugative plasmid $[4,5]$. Conjugative transfer of plasmids mediating mupirocin resistance has followed the same course [6-12] except that co-transfer was not reported until early 1997 [13].

This report describes mupirocin resistance plasmids in isolates from three patients in a single hospital ward.

Received 3 April 2000; revised version received 25 April 2000; accepted 1 May 2000.

* Author for correspondence: S. A. Howell.

Present address: Department of Medical Mycology, St John's Institute of Dermatology, King's College London, St Thomas' Hospital, London SE1 7EH, UK. Fax No: 020 79228227

\section{Materials and methods}

Five isolates of mupirocin- and methicillin-resistant Staphylococcus aureus were received from routine clinical sources in an on-going study of mupirocin resistance in staphylococci. All were re-tested for resistance to the following antibiotics by disk diffusion tests on Oxoid blood agar base medium (BAB; Oxoid) or on Direct Sensitivity Test Agar (Difco) containing lysed horse blood at $37^{\circ} \mathrm{C}$ except for methicillin which was tested at $30^{\circ} \mathrm{C}$ : amoxycillin $25 \mu \mathrm{g}$, chloramphenicol $10 \mu \mathrm{g}$, ciprofloxacin $1 \mu \mathrm{g}$, clindamycin $2 \mu \mathrm{g}$, erythromycin (Em) $15 \mu \mathrm{g}$, fusidic acid $10 \mu \mathrm{g}$, gentamicin $(\mathrm{Gm}) 10 \mu \mathrm{g}$, methicillin $5 \mu \mathrm{g}$, minocycline $(\mathrm{Mn})$ $30 \mu \mathrm{g}$, mupirocin (Mu) $200 \mu \mathrm{g}$, neomycin $30 \mu \mathrm{g}$, penicillin (Pc) 10 units, streptomycin $10 \mu \mathrm{g}$, tetracycline (Tc) $10 \mu \mathrm{g}$, trimethoprim $5 \mu \mathrm{g}$ and vancomycin $30 \mu \mathrm{g}$. Recipient strains of $S$. aureus were Blll and NCTC8325 made resistant to fusidic acid and rifampicin by serial culture on increasing amounts of these antibiotics; these strains have been shown previously to act as good recipients [1,2].

Conjugative transfer was performed by a variation of filter mating, in which recipient strains grown overnight on $\mathrm{BAB}$ containing rifampicin $80 \mu \mathrm{g} / \mathrm{ml}$ and donor strains grown overnight on $\mathrm{BAB}$ containing mupirocin 
$80 \mu \mathrm{g} / \mathrm{ml}$ were suspended in broth, mixed and centrifuged to form a pellet. The supernate was removed and the pellet was resuspended in $c .0 .25 \mathrm{ml}$ of sterile distilled water and inoculated as a dense spot on BAB. After overnight incubation, the growth was removed and resuspended in c. $0.5 \mathrm{ml}$ of sterile distilled water; this suspension and a 1 in 10 dilution were then inoculated on to $\mathrm{BAB}$ containing both rifampicin $80 \mu \mathrm{g} / \mathrm{ml}$ and mupirocin $100 \mu \mathrm{g} / \mathrm{ml}$. After incubation, presumed transconjugant colonies were subcultured to purity and tested for resistance to antibiotics as described above.

Plasmid profiles were established by a method modified from that of Naidoo [5]. Briefly, cultures from BAB plates containing mupirocin $80 \mu \mathrm{g} / \mathrm{ml}$ were suspended in $2.5 \mathrm{M} \mathrm{NaCl}$ containing lysostaphin (AMBI, Wilts) $50 \mu \mathrm{g} / \mathrm{ml}$ and incubated at $37^{\circ} \mathrm{C}$ for $80 \mathrm{~min} ; 2$ volumes of Brij 58 solution containing $(\mathrm{g} / \mathrm{L})$ Brij $5810 \mathrm{~g}$, deoxycholic acid 4 g, EDTA $20 \mathrm{~g}$, pH8-9, were added to give a viscous solution. Cell debris was pelleted by centrifugation and the supernate was removed; RNAase A (Sigma) $50 \mu \mathrm{g} / \mathrm{ml}$ was then added to the supernate and the mixture was incubated at $37^{\circ} \mathrm{C}$ for $30 \mathrm{~min}$. Proteinase K (Boehringer Mannheim, Sussex) was added to a final concentration of $100 \mu \mathrm{g} / \mathrm{ml}$ and the mixture was incubated at $37^{\circ} \mathrm{C}$ for $45 \mathrm{~min}$. One volume of cold absolute ethanol was added and the mixture was stored overnight at $-20^{\circ} \mathrm{C}$. Precipitated DNA was centrifuged, washed in cold ethanol and the tubes were allowed to dry. DNA was then resuspended in $60 \mu \mathrm{l}$ of TE buffer (10 mM Trizma base, $1 \mathrm{~mm}$ EDTA, $\mathrm{pH}$ 8) for $1 \mathrm{~h}$ at room temperature and the mixture was stored at $-20^{\circ} \mathrm{C}$ until required.

Restriction endonuclease digests were made with Eco RI (Pharmacia, Herts) and HindIII (BRL, Paisley) according to the manufacturers' instructions. Plasmids from Escherichia coli V517 were used as size markers and were extracted by standard methods [14]. Other mol. wt markers were $\lambda$ phage cut by HindIII (Gibco BRL).

Hybridisation was performed as described by Rahman et al. [15]. Briefly, EcoRI digests were transferred to a nylon membrane. The probe comprising the $4.05-\mathrm{kb}$ EcoRI fragment of the mupirocin gene was labelled by the BioNick labelling system (Life Technologies, Scotland). Biotinylated DNA was detected with the
BluGene non-radioactive detection kit (Life Technologies) according to the manufacturer's instructions. Except where stated, all chemicals were the appropriate grade from Sigma.

Whole-cell restriction digests with SmaI (Pharmacia) and pulsed-field gel electrophoresis (PFGE) were performed according to the method of Khambaty et al. [16]. Briefly, cells grown in Brain Heart Infusion Broth (Oxoid) overnight at $37^{\circ} \mathrm{C}$ in an orbital incubator were pelleted by centrifugation. After being washed, the pellet was resuspended in TES buffer $(10 \mathrm{mM}$ Trizma base, $50 \mathrm{~mm}$ EDTA, $1 \mathrm{M} \mathrm{NaCl}, \mathrm{pH} 8.0$ ); the suspension was mixed with an equal volume of lowmelting temperature agarose (BioRad, Herts) and the mixture was set in plastic moulds. When set, the agarose plugs were placed in a container with $\mathrm{TE}$ buffer containing lysostaphin $50 \mu \mathrm{g} / \mathrm{ml}$ for $4 \mathrm{~h}$ at $37^{\circ} \mathrm{C}$. Lysostaphin solution was replaced by proteinase $\mathrm{K}$ in NDS buffer $(10 \mathrm{mM}$ Tris, $0.5 \mathrm{M}$ EDTA, laurylsarcosine $1 \%, \mathrm{NaOH} 2 \%$ ) and incubated overnight at $50^{\circ} \mathrm{C}$. This was followed by two washes with phenylmethylsulphonylfluoride in TE buffer and three washes in TE buffer alone, each of which was allowed to remain in contact with the plugs for $45 \mathrm{~min}$. Restriction with SmaI was done according to the manufacturer's instructions. Electrophoresis was in a Pharmacia hexagonal array system with a 5 -s pulse time for $18 \mathrm{~h}$ at $12^{\circ} \mathrm{C}$ with agarose $1 \%$ gels and TBE ( $89 \mathrm{~mm}$ Tris, $2.5 \mathrm{~mm}$ EDTA, $32 \mathrm{~mm}$ boric acid) buffer.

\section{Results}

The MRSA isolates exhibited two different antibiotic resistance patterns as shown in Table 1. PFGE of Sma I digests showed that isolates 4516, 4528, 4529 and 4538 were indistinguishable in pattern but isolate 4515 differed by at least seven major bands and was, therefore, considered to represent a distinct strain (data not shown). Furthermore, this latter isolate (designated strain A) was typical 'aureus' in colony colour whereas the remainder (designated strain B) were white. Plasmids $>30 \mathrm{~kb}$ were seen in all isolates. Strain A possessed one large plasmid but also possessed plasmids of $6.7 \mathrm{~kb}, 3.8 \mathrm{~kb}$ and $2.7 \mathrm{~kb}$. The four strain $\mathrm{B}$ isolates possessed no small plasmids but did contain two or three large plasmids which were difficult to resolve by gel electrophoresis (data not shown).

Table 1. Characteristics of MRSA strains resistant to mupirocin

\begin{tabular}{|c|c|c|c|c|}
\hline Patient & Isolate No. & Date isolated & Resistance pattern & Colony colour \\
\hline A strain A & 4515 & 11 March & $\mathrm{Pc}, \mathrm{Tc}, \mathrm{Em}, \mathrm{Me}, \mathrm{Mu}$ & Aureus \\
\hline \multirow[t]{2}{*}{ B strain B } & 4516 & 15 March & $\mathrm{Pc}, \mathrm{Em}, \mathrm{Gm}, \mathrm{Me}, \mathrm{Mu}$ & White \\
\hline & 4529 & 15 March & Pc, Em, Gm Me Mu & White \\
\hline \multirow[t]{2}{*}{ C strain B } & 4538 & 15 March & $\mathrm{Pc}, \mathrm{Em}, \mathrm{Gm}, \mathrm{Me}, \mathrm{Mu}$ & White \\
\hline & 4528 & 17 March & $\mathrm{Pc}, \mathrm{Em}, \mathrm{Gm}, \mathrm{Me}, \mathrm{Mu}$ & White \\
\hline
\end{tabular}

All isolates were tested for susceptibility to penicillin $(\mathrm{Pc})$, tetracycline $(\mathrm{Tc})$, erythromycin $(\mathrm{Em})$, gentamicin $(\mathrm{Gm})$, methicillin $(\mathrm{Me})$, mupirocin $(\mathrm{Mu})$ and other antibiotics as described in the text. Only resistances are recorded in the table. 
Conjugative transfer occurred from all isolates, with diverse results (Table 2). Plasmid profiles of a selection of the transconjugants indicated that two features could be detected. The first feature was that in some instances genes governing penicillinase prodution were apparently located on the same plasmid as the gene for mupirocin resistance, as only one large plasmid was transferred into 11 strain $B$ transconjugants, six exhibiting resistance to mupirocin $\left(\mathrm{Mu}^{\mathrm{R}}\right)$ and five exhibiting resistance to mupirocin and penicillin $\left(\mathrm{Mu}^{\mathrm{R}} \mathrm{Pc}^{\mathrm{R}}\right)$. Two large plasmids were seen in the transconjugant exhibiting resistance to gentamicin in addition to mupirocin and penicillin $\left(\mathrm{Gm}^{\mathrm{R}} \mathrm{Mu}^{\mathrm{R}} \mathrm{Pc}^{\mathrm{R}}\right)$.

The second feature was that, in transconjugants of strain A, co-transfer of plasmids mediating resistance to erythromycin and tetracycline had occurred. Thirteen transconjugants of strain A into Blll were examined for plasmid profile. In addition to the single large plasmid, six possessed the $6.7-\mathrm{kb}$ plasmid and were the only tetracycline-resistant $\left(\mathrm{Tc}^{\mathrm{R}}\right)$ transconjugants; 12 possessed the $2.7-\mathrm{kb}$ plasmid and were the only erythromycin-resistant $\left(\mathrm{Em}^{\mathrm{R}}\right)$ transconjugants, and 10 possessed the $3.8-\mathrm{kb}$ plasmid. No function could be assigned to this $3.8-\mathrm{kb}$ plasmid on the basis of antibiotic resistance. This plasmid appeared in all six $\mathrm{Mu}^{\mathrm{R}} \mathrm{Em}^{\mathrm{R}} \mathrm{Tc}^{\mathrm{R}}$ transconjugants and in three of the six $\mathrm{Mu}^{\mathrm{R}} \mathrm{Em}^{\mathrm{R}}$ transconjugants, but not in the only $\mathrm{Mu}^{\mathrm{R}}$ transconjugant tested.

When cut by restriction endonuclease EcoRI, the plasmid associated with resistance to mupirocin only $\left(\mathrm{Mu}^{\mathrm{R}}\right.$ plasmid transferred from strain A isolate 4515) and that associated with mupirocin resistance and penicillinase production $\left(\mathrm{Mu}^{\mathrm{R}} \mathrm{Pc}^{\mathrm{R}}\right.$ plasmid from strain $\mathrm{B}$ isolate 4528) had six fragments in common; the $\mathrm{Mu}^{\mathrm{R}}$ plasmid also yielded a fragment of $7.2 \mathrm{~kb}$ and the $\mathrm{Mu}^{\mathrm{R}} \mathrm{Pc}^{\mathrm{R}}$ plasmid one of $13.2 \mathrm{~kb}$ (Fig. 1). HindIII digests had 14 fragments in common with a fragment of $5.3 \mathrm{~kb}$ in $\mathrm{Mu}^{\mathrm{R}}$ and fragments of $6.1 \mathrm{~kb}$ and $5.9 \mathrm{~kb}$ in $\mathrm{Mu}^{\mathrm{R}} \mathrm{Pc}^{\mathrm{R}}$ plasmids. Double digests with these two enzymes yielded 17 visible fragments in common with a fragment of $1.82 \mathrm{~kb}$ in $\mathrm{Mu}^{\mathrm{R}}$ and fragments of $6.1 \mathrm{~kb}$ and $2.1 \mathrm{~kb}$ in $\mathrm{Mu}^{\mathrm{R}} \mathrm{Pc}^{\mathrm{R}}$ plasmids. Both plasmids hybridised with the mupA probe to the $10.6 \mathrm{~kb}$ EcoRI fragment and to a $4.3 \mathrm{~kb}$ HindIII fragment; this latter was also the fragment size of the chief hybridisation band in the double digests. Plasmids from another nine strain B transconjugants (five resistant to mupirocin

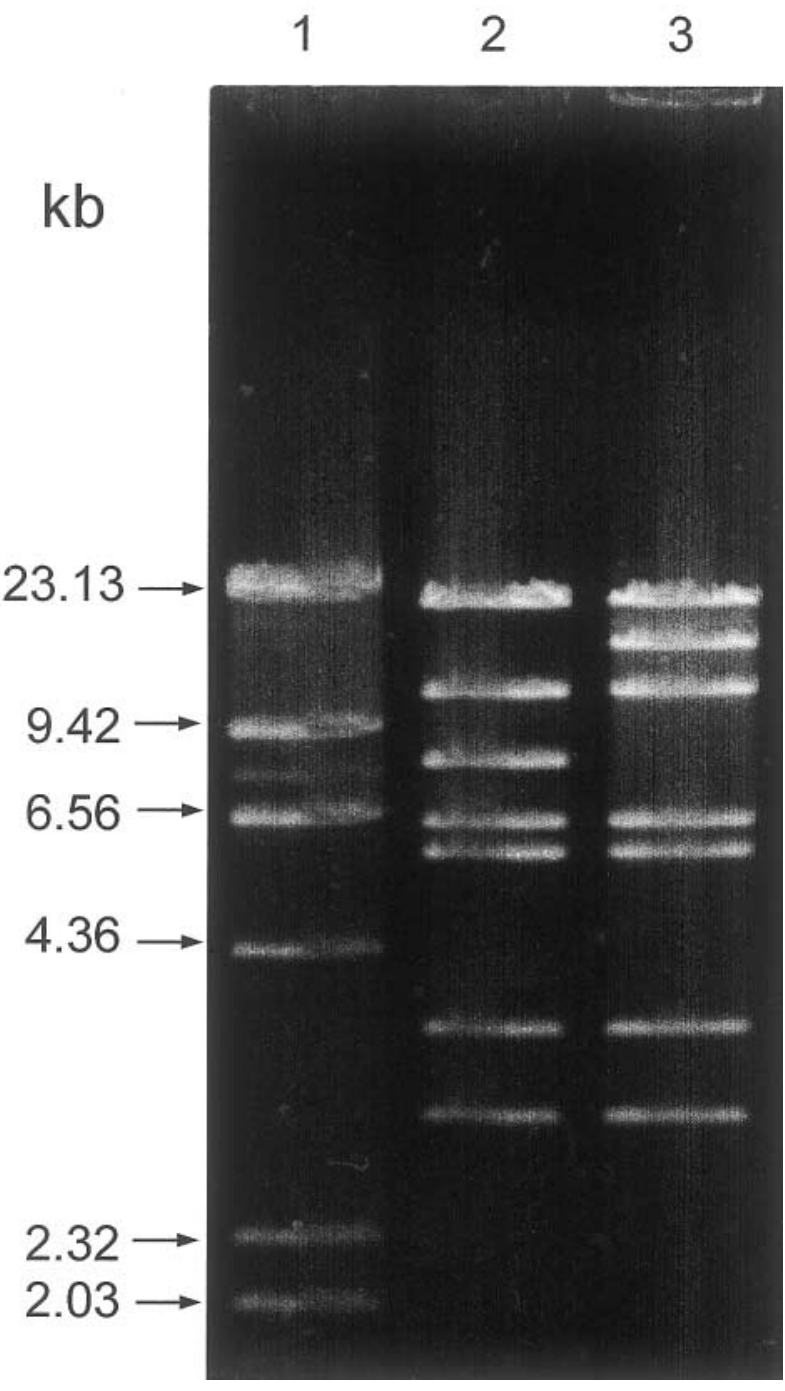

Fig. 1. EcoRI restriction patterns of plasmids associated with resistance to mupirocin and mupirocin + penicillin. Lane 1; $\lambda$ DNA HindIII; $2, \mathrm{Mu}^{\mathrm{R}}$ transconjugant from $45153, \mathrm{Mu}^{\mathrm{R}} \mathrm{Pc}^{\mathrm{R}}$ transconjugant from 4528 .

only and four to penicillin and mupirocin) were cut with EcoRI only and gave the same patterns as described above.

Repeated incubation in broth of the transconjugant resistant to gentamicin as well as mupirocin and penicillin gave isolates resistant to gentamicin only (data not shown). The plasmid from an isolate that was only $\mathrm{Gm}^{\mathrm{R}}$ gave seven visible bands on EcoRI

Table 2. Resistance patterns of transconjugants from MRSA to recipients and number of transconjugants recovered

\begin{tabular}{|c|c|c|c|c|c|c|c|}
\hline \multirow[b]{2}{*}{ Isolate code } & \multicolumn{7}{|c|}{ Number of transconjugants with resistance pattern } \\
\hline & $\mathrm{Mu}^{\mathrm{R}}$ only & $\mathrm{Mu}^{\mathrm{R}} \mathrm{Pc}^{\mathrm{R}}$ & $\mathrm{Mu}^{\mathrm{R}} \mathrm{Tc}^{\mathrm{R}}$ & $\mathrm{Mu}^{\mathrm{R}} \mathrm{Em}^{\mathrm{R}}$ & $\mathrm{Mu}^{\mathrm{R}} \mathrm{Tc}^{\mathrm{R}} \mathrm{Em}^{\mathrm{R}}$ & $\mathrm{Mu}^{\mathrm{R}} \mathrm{Pc}^{\mathrm{R}} \mathrm{Gm}^{\mathrm{R}}$ & $\mathrm{Mu}^{\mathrm{R}} \mathrm{Gm}^{\mathrm{R}}$ \\
\hline 4515 & 43 & 0 & 2 & 22 & 17 & 0 & 0 \\
\hline 4516 & 13 & 1 & - & 0 & - & 1 & 0 \\
\hline 4529 & 9 & 44 & - & 0 & - & 0 & 0 \\
\hline 4538 & 15 & 52 & - & 4 & - & 0 & 1 \\
\hline 4528 & 31 & 12 & - & 2 & - & 0 & 0 \\
\hline
\end{tabular}

-, Not applicable. 
restriction, only two of which appeared to be similar to bands in the $\mathrm{Mu}^{\mathrm{R}}$ and $\mathrm{Mu}^{\mathrm{R}} \mathrm{Pc}^{\mathrm{R}}$ plasmids, and was, therefore, considered distinct from these latter plasmids.

\section{Discussion}

It is apparent that two distinct strains of mupirocinresistant MRSA were present in the ward within a few days; one (strain A) was typical 'aureus' in colony colour, was resistant to erythromycin and tetracycline by plasmid-borne genes and also carried a plasmid with no apparent resistance function; the other (strain B) was white in colony colour and had no small plasmids. In PFGE of Sma I digests, these two strains were also quite distinct. Nevertheless, these strains apparently shared a plasmid (or plasmids) of $c .60 \mathrm{~kb}$ in which the MupA gene was encoded on an EcoRI fragment of $c$. $10.6 \mathrm{~kb}$ and a HindIII fragment of $c .4 .3 \mathrm{~kb}$ with all restriction fragments generated by EcoRI, HindIII and $E c o$ RI $+H i n$ dIII in common except for a $c .13 .2-\mathrm{kb}$ EcoRI fragment presumably encoding a penicillinase production gene. The $\mathrm{Mu}^{\mathrm{R}}$ plasmid in strain A might have transferred to strain B or both might have had a common (undetected) origin. None of the 84 transconjugants from strain A exhibited penicillin resistance, in contrast to 75 of 110 transconjugants from strain B, which might suggest that penicillinase production was chromosomally located in strain A. However, it should be noted that the distribution of $\mathrm{Mu}^{\mathrm{R}}$ versus $\mathrm{Mu}^{\mathrm{R}} \mathrm{Pc}^{\mathrm{R}}$ differed between the transconjugants from the four strain B isolates (Table 2). Rowland and Dyke [17] have reported a penicillinase transposon (Tn552) of $6.5 \mathrm{~kb}$ which might suggest that the penicillinase genes were an addition to the putative 'mupirocin resistance' plasmid of strain A. In contrast, Udo et al. [12] have suggested that a mupirocin gene was incorporated into a plasmid 'at the expense of the penicillinase gene' and Morton et al. [18] have reported the apparent exchange of gentamicin and other resistance determinants for a mupA gene. The presence of the insertion element IS257 has been implicated in the integration of a tetracycline plasmid into one possessing muрA and with the doubling of the muр $A$ gene [18] and with the intergration of mup $A$ into a pre-existing plasmid [19], but insertion elements were not sought in this study.

The 6.7-kb plasmid associated with $\mathrm{Tc}^{\mathrm{R}}$ in strain $\mathrm{A}$ is unusual, as $\mathrm{Tc}^{\mathrm{R}}$ plasmids from staphylococci of human origin are more usually $c .4 .2 \mathrm{~kb}$; however, $\mathrm{Tc}^{\mathrm{R}}$ plasmids between $c$. 6 and $10 \mathrm{~kb}$ are found in staphylococci from the skin of pigs [20].

No small plasmids were observed in the four strain B isolates or in $\mathrm{Em}^{\mathrm{R}}$ transconjugants from these isolates and it is presumed that a transposon such as $\operatorname{Tn} 917$ mediated this resistance, but this possibility was not investigated here. Transposon transfer in conjugation experiments has been well documented and transposons mediating $\mathrm{Em}^{\mathrm{R}}$ have been reported upstream of the mec gene in MRSA [21, 22].

Co-transfer of small plasmids by conjugative $\mathrm{Gm}^{\mathrm{R}}$ plasmids has been well documented $[4,5]$ but was not encountered amongst the nearly 50 distinct $\mathrm{Mu}^{\mathrm{R}}$ plasmids investigated in earlier studies $[8,9]$. However, in early 1997 Udo et al. [13] reported co-transfer of a $3.5-\mathrm{kb}$ chloramphenicol resistance plasmid by $\mathrm{Mu}^{\mathrm{R}}$ plasmid from $S$. haemolyticus. This present report confirms that co-transfer of small plasmids, some of which encode other antibiotic resistances, may occur in strains bearing $\mathrm{Mu}^{\mathrm{R}}$ plasmids as well as those with plasmids mediating $\mathrm{Gm}^{\mathrm{R}}$.

\section{References}

1. Naidoo J, Noble WC. Transfer of gentamicin resistance between strains of Staphylococcus aureus on skin. J Gen Microbiol 1978; 107: 391-393.

2. Naidoo J, Noble WC. Transfer of gentamicin resistance between coagulase-negative and coagulase-positive staphylococci on skin. J Hyg 1981; 86: 183-187.

3. Forbes BA, Schaberg DR. Transfer of resistance plasmids from Staphylococcus epidermidis to Staphylococcus aureus: evidence for conjugative exchange of resistance. J Bacteriol 1983; 153: 627-634.

4. McDonnell RW, Sweeney HM, Cohen S. Conjugational transfer of gentamicin resistance plasmids intra- and interspecifically in Staphylococcus aureus and Staphylococcus epidermidis. Antimicrob Agents Chemother 1983; 23: 151-160.

5. Naidoo J. Interspecific co-transfer of antibiotic resistance plasmids in staphylococci in vivo. J Hyg 1984; 93: 59-66.

6. Udo EE, Love $\mathrm{H}$, Grubb WB. Intra-and inter-species mobilisation of non-conjugative plasmids in staphylococci. J Med Microbiol 1992; 37: 180-186.

7. Rahman M, Noble WC, Cookson B. Mupirocin-resistant Staphylococcus aureus. Lancet 1987; 2: 387.

8. Rahman M, Noble WC, Cookson B. Transmissible mupirocin resistance in Staphylococcus aureus. Epidemiol Infect 1989; 102: 261-270.

9. Rahman M, Connolly S, Noble WC, Cookson B, Phillips I. Diversity of staphylococci exhibiting high-level resistance to mupirocin. J Med Microbiol 1990; 33: 97-100.

10. Moy JA, Caldwell-Brown D, Lin AN, Pappa KA, Carter DM. Mupirocin-resistant Staphylococcus aureus after long-term treatment of patients with epidermolysis bullosa. $\mathrm{J} \mathrm{Am} \mathrm{Acad}$ Dermatol 1990; 22: 893-895.

11. Layton MC, Perez M, Heald P, Patterson JE. An outbreak of mupirocin-resistant Staphylococcus aureus on a dermatology ward associated with an environmental reservoir. Infect Control Hosp Epidemiol 1993; 14: 369-375.

12. Udo EE, Pearman JW, Grubb WB. Emergence of high-level mupirocin resistance in methicillin-resistant Staphylococcus aureus in Western Australia. J Hosp Infect 1994; 26: 157-165.

13. Udo EE, Jacob LE, Mokadas EM. Conjugative transfer of high-level mupirocin resistance from Staphylococcus haemolyticus to other staphylococci. Antimicrob Agents Chemother 1997; 41: 693-695.

14. Macrina FL, Kopecko DJ, Jones KR, Ayers DJ, McCowen SM. A multiple plasmid-containing Escherichia coli strain: convenient source of size reference plasmid molecules. Plasmid 1978; 1: 417-420.

15. Rahman M, Noble WC, Dyke KGH. Probes for the study of mupirocin resistance in staphylococci. J Med Microbiol; 39: 446-449.

16. Khambaty FM, Bennett RW, Shah DB. Application of pulsedfield gel electrophoresis to the epidemiological characterization of Staphylococcus intermedius implicated in a food-related outbreak. Epidemiol Infect 1994; 113: 75-81.

17. Rowland S-J, Dyke KGH. Characterization of the staphylococcal beta-lactamase transposon Tn552. EMBO J 1989; 8: 2761-2773. 
18. Morton TM, Johmston JL, Patterson J, Archer GL. Characterization of a conjugative staphylococcal mupirocin resistance plasmid. Antimicrob Agents Chemother 1995; 39: 1272-1280.

19. Needham C, Rahman M, Dyke KGH, Noble WC. An investigation of plasmids from Staphylococcus aureus that mediate resistance to mupirocin and tetracycline. Microbiology 1994; 140: 2577-2583.

20. Schwarz S, Noble WC. Tetracycline resistance genes in staphylococci from the skin of pigs. J Appl Bacteriol 1994; 76: $320-326$.
21. Matthews PR, Inglis B, Stewart RP. Clustering of resistance genes in the mec region of the chromosome of Staphylococcus aureus. In: Novick RP (ed) Molecular biology of the staphylococci. New York, VCH Publishers. 1990: 69-83.

22. Chikramane SG, Matthews PR, Noble WC, Stewart PR, Dublin DT. Tn554 inserts in methicillin-resistant Staphylococcus aureus from Australia and England; comparison with an American methicillin-resistant group. J Gen Microbiol 1991; 137: $1303-1311$. 